Research Article

\title{
Complex System Analysis of Blumeria graminis f.sp. tritici Isolates Collected in Central Hebei Province, China
}

\author{
Qingping Zhou, ${ }^{1,2}$ Lingli $\mathrm{Li}^{3}{ }^{3}$ and Long Wang $\mathbb{C}^{2}$ \\ ${ }^{1}$ College of Mathematics and Computing Science, Tangshan Normal University, Tangshan 063000, Hebei Province, China \\ ${ }^{2}$ Innovation and Entrepreneurship Office, Tangshan Normal University, Tangshan 063000, Hebei Province, China \\ ${ }^{3}$ College of Physical Science and Technology, Tangshan Normal University, Tangshan 063000, Hebei Province, China
}

Correspondence should be addressed to Long Wang; wanglong112011@yeah.net

Received 24 November 2020; Revised 29 March 2021; Accepted 1 April 2021; Published 12 April 2021

Academic Editor: Junhai Ma

Copyright (c) 2021 Qingping Zhou et al. This is an open access article distributed under the Creative Commons Attribution License, which permits unrestricted use, distribution, and reproduction in any medium, provided the original work is properly cited.

\begin{abstract}
Wheat powdery mildew (WPM), caused by Blumeria graminis f.sp. tritici, is a significant disease of wheat throughout the world and has resulted in substantial yield and economic losses in wheat production. It is particularly important to understand the population distribution and genetic resistance of B. graminis f.sp. tritici. In 2019, the cumulative incidence of wheat powdery mildew in China was nearly 8.7 million $\mathrm{hm}^{2}$, which seriously affected the safe production of wheat in China. However, the proportion of disease-resistant wheat varieties in actual production was relatively low, and effective disease-resistant genes were lacking. As one of the main wheat-producing provinces in China, it is of great significance for normal wheat production to understand powdery mildew resistance in Hebei province. In this study, using wheat seedling culture in vitro, the physiological races of wheat powdery mildew in central Hebei province were identified, and the population toxicity frequency was analyzed. The results were as follows: (1) 36 strains were purified and 20 physiological races were identified. Among them, the dominant race is 015 , and the distribution frequency is $16.7 \%$. Race 077 is the second dominant race. (2) The frequency of virulence genes $V_{\text {Era }}, V_{8}$, $\mathrm{V}_{1}, \mathrm{~V}_{3 \mathrm{c}}$, and $\mathrm{V}_{3 \mathrm{f}}$ in population toxicity frequency analysis was more than $70 \%$, while the frequency of virulence genes $\mathrm{V}_{2,}$, MID, $\mathrm{V}_{20}$, $\mathrm{V}_{21}, \mathrm{~V}_{4 \mathrm{~b}}$, and $\mathrm{V}_{4}$ was less than $16.7 \%$, and $46 \%$ of virulence genes of powdery mildew were higher than $40 \%$. It shows that the virulence gene frequency of powdery mildew in Hebei province is high, and the varieties containing $\mathrm{Pm}_{2+\mathrm{MID}}, \mathrm{Pm}_{20}, \mathrm{Pm}_{21}, \mathrm{Pm}_{1 \mathrm{~b}}$, $\mathrm{Pm}_{1}$, and other disease resistance genes have a certain value inbreeding.
\end{abstract}

\section{Introduction}

The issue of food security plays a vital role in the stable development of a country's economy and society. In China, the steady growth of grain production is the basis of food security. As one of the three major grain varieties, wheat accounts for about $5 \%$ of China's total grain output $[1,2]$. At the same time, wheat is the main food source for residents in northern China and plays an important role in its dietary structure, so the fluctuation of wheat production has a great impact on national food security [3-5]. Since the 1990s, wheat production in China has fluctuated greatly. In 1992 and 2004, wheat yield showed the characteristics of a "roller coaster," that is, from low to high in the first 6 years and from high to low in the last 6 years, from 9595 million tons in 1992 to 12329 million tons in $2004[6,7]$. The maximum difference of yield fluctuation was 2734 million tons, with a fluctuation of $28.5 \%$, but the wheat yield in 2003 was 8649 million tons. It is the lowest since the $1990 \mathrm{~s}, 29.8 \%$ lower than in 1997 . Wheat production has gradually begun to recover since 2003, with an average annual growth rate of $2.83 \%$, with an output of 13144 million tons in 20189 [8, 9]. Lack of understanding and research on the regularity of wheat yield fluctuation will lead to passive, blind, and even mistakes in macromanagement. Therefore, the scientific analysis of the characteristics and influencing factors of wheat yield fluctuation in China and the prediction based on it is of great practical significance to stabilize wheat production and development and achieve the goal of food security $[10,11]$. 
Wheat yield fluctuations: the variation rate (fluctuation index) was used to measure the yield volatility of wheat. Variation rate (RV) is a commonly used index to measure the periodicity of economic variables, which is usually used to express the short-term fluctuation intensity of economic variables, which is the deviation of the actual observation from its long-term trend. The calculation formula is

$$
\mathrm{RV}=\frac{y_{t}-\widehat{y}_{t}}{y_{t}} \times 100 \%,
$$

where $y_{t}$ is the actual yield of wheat in $t$ period, $\widehat{y}_{t}$ is the trend value of wheat yield in $t$ period, and $y_{t}-\widehat{y}_{t}$ is the economic variable after eliminating the long-term trend. The absolute volatility represents the absolute deviation of the actual observed value of the $t$ year from its long-term trend. The absolute value of RV indicates the stability of the variable. The greater the absolute value, the worse the stability, indicating that the variable is farther away from the long-term trend. The smaller the absolute value is, the better the stability is, indicating that the variable is closer to the long-term trend [12].

Volatility index determination: the long-term trend of total wheat yield is fitted by the grey system model.

$$
X(t+1)=45573.20 e^{0.01852 t}-44827.02 .
$$

Prediction accuracy of the model:

$$
\mathrm{MAPE}=\frac{1}{n} \times \sum \frac{y_{t}-\widehat{y}_{t}}{y_{t}} \times 100 \%=8.68 \% .
$$

The model simulates the change characteristics of the data, and after eliminating the long-term trend, the fluctuation index of total wheat yield over the years can be calculated (Figures 1-3).

From 2009 to 2016, the total area of wheat cultivation in China increased from 24.4424 million hectares to 24.694 million hectares, an increase of 1.03 percent, and then declined for two consecutive years. In 2018, the planting area of 24.27 million hectares was the lowest in a decade, a decrease of 240000 hectares compared with 2017 (Figure 1).

The data of the market panoramic survey and investment prospect forecast report of China's wheat planting industry from 2019 to 2025 show that China's wheat output per unit area has increased for eight consecutive years from 2009 to 2017, with an average annual yield of $5.48 \mathrm{t} / \mathrm{ha}$ in 2018 and $5.42 \mathrm{t} / \mathrm{ha}$ in 2018 . The interannual increase of wheat yield changed greatly, and the proportion of annual increase of wheat per unit yield changed from high-speed growth stage to low-speed growth stage (Figure 2).

From 2009 to 2017, China's total wheat output increased for eight consecutive years and decreased for the first time in 2018. The total wheat output was 131.4405 million tons, $2.15 \%$ down compared with 2017. The interannual growth rate of wheat output fluctuated greatly, except for the negative growth of total wheat output in 2018. All other years showed positive growth, with the highest growth rate in 2014 (Figure 3).

Wheat powdery mildew (WPM), caused by Blumeria graminis f.sp. tritici, is a significant disease of wheat throughout the world and has resulted in substantial yield and economic losses in wheat production [13-15]. The prevalence of B. graminis f.sp. tritici starts from the 1980s, and the degree of harm and extension become enlarged increasingly [16-19]. The average annual incidence area of powdery mildew in major wheat areas in China is more than 6 million $\mathrm{hm}^{2}$. In 2019, the cumulative occurrence area of wheat powdery mildew in China was close to 8.7 million $\mathrm{hm}^{2}$, and the average diseased leaf rate in individual regions was even as high as $100 \%$ [20-22]. In recent years, the damage of wheat powdery mildew continues to expand, showing a trend of gradual aggravation from south to north, which poses a serious threat to the safe production of wheat in China, but the proportion of resistant wheat varieties is low, and there is a lack of effective resistance genes [23-26]. Since 2000, there have been few reports on the systematic investigation of powdery mildew resistance of wheat varieties in Hebei province. Therefore, the identification of known effective resistance genes in Hebei approved varieties and high-generation lines is of great significance for the rational collocation of varieties and rational use of resistance sources to prevent and reduce the damage of wheat powdery mildew. At the same time, the continuous mining of new resistance sources and new genes is also particularly important.

\section{Materials and Methods}

2.1. Experimental Materials. Twenty-six powdery mildew resistance gene materials are known in the test, which is expressed as the name of the variety (line) and the powdery mildew resistance gene carried. They are Afu (susceptible control), Ulka/8Cc $\left(\mathrm{Pm}_{2}\right)$, Era, Caucasus $\left(\mathrm{Pm}_{8}\right), \mathrm{CI}_{12632}$ $\left(\mathrm{Pm}_{2,6}\right)$, MarisHuntsman $\left(\mathrm{Pm}_{2,6}\right.$, $)$, Kenguia $1\left(\mathrm{Pm}_{4}\right)$, Baimian $3\left(\mathrm{Pm}_{4}\right)$, Xiaobai Dong $\left(\mathrm{Pm}_{\mathrm{XBD}}\right)$, Chancellor, $\mathrm{Ax}-$ minster/8Cc $\left(\mathrm{Pm}_{1}\right)$, Asosan/8Cc $\left(\mathrm{Pm}_{3 \mathrm{a}}\right)$, Chul/8Cc $\left(\mathrm{Pm}_{3 \mathrm{~b}}\right)$, Sonora/8Cc $\left(\mathrm{Pm}_{3 \mathrm{c}}\right)$, MichigenAmber/8Cc $\left(\mathrm{Pm}_{3 \mathrm{f}}\right)$, Khapli/ 8Cc $\left(\mathrm{Pm}_{4 \mathrm{a}}\right)$, Armada $\left(\mathrm{Pm}_{4 \mathrm{~b}}\right)$, Hope/8Cc $\left(\mathrm{Pm}_{5}\right)$, Timglen $\left(\mathrm{Pm}_{6}\right), \mathrm{CI}_{14189}\left(\mathrm{Pm}_{7}\right)$, Amigo $\left(\mathrm{Pm}_{17}\right),\left(\mathrm{Pm}_{19}\right),\left(\mathrm{Pm}_{20}\right)$, Yangmai $5 / \mathrm{Sub} .6 \mathrm{v}\left(\mathrm{Pm}_{21}\right)$, Maris Dove $\left(\mathrm{Pm}_{2, \mathrm{Mid}}\right)$, and Normandie $\left(\mathrm{Pm}_{1,2,9}\right)$. The above materials are provided by the Hebei Academy of Agricultural Sciences.

\subsection{Experimental Methods}

2.2.1. Strains Collection and Preservation. Since the wheat growing season in early June 2019, 48 standard samples of fresh wheat powdery mildew were collected in Shijiazhuang City, Xingtai City, Hengshui City, Handan City, Baoding City, and other cities in the central part of Hebei province. Put it in clean plastic bags and take it back to the laboratory to inoculate on the sterile wheat seedlings already planted in the laboratory. After the disease, pick up a single colony with a fine brush or cutoff the single bacteria to be reinoculated. Cover the plastic flowerpot with a glass bottle with 4 6 layers of gauze or a layer of filter paper at the top and number; the culture is in a constant temperature incubator (temperature $14-20^{\circ} \mathrm{C}$, light $14 \mathrm{~h} / \mathrm{d}$ ) and prepare to inoculate the bacteria. 


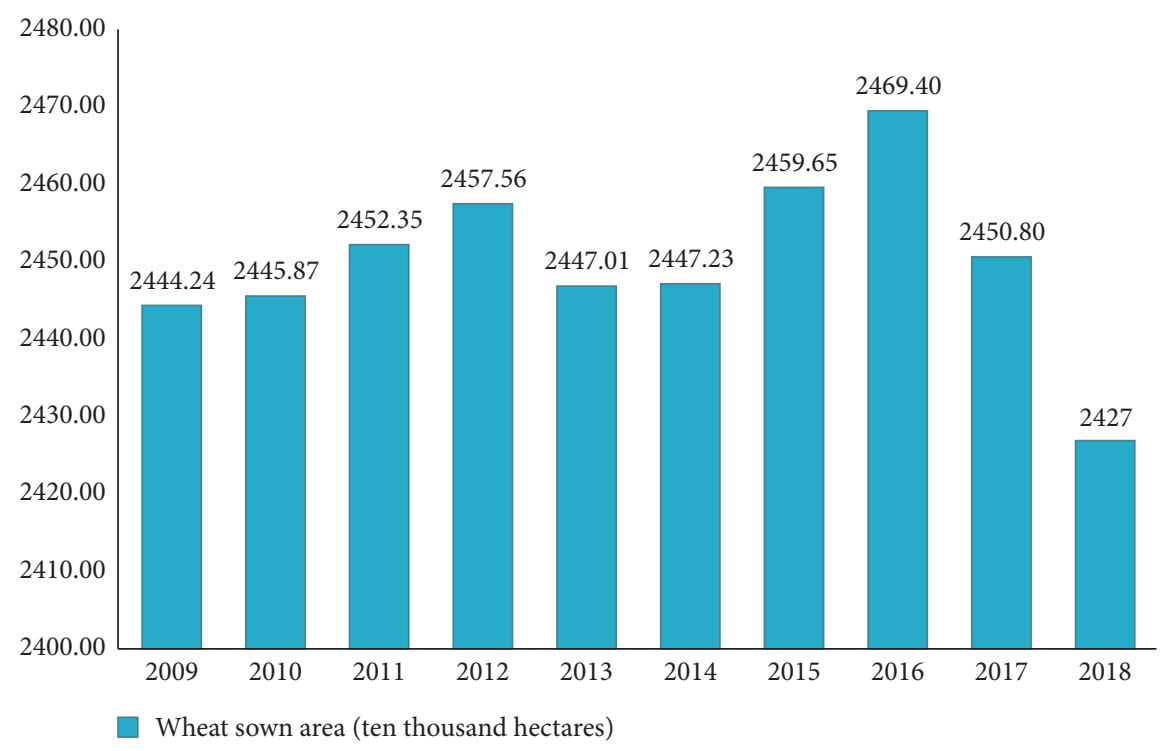

Figure 1: Changes in China's wheat planting area from 2009 to 2018 (source: National Bureau of Statistics).

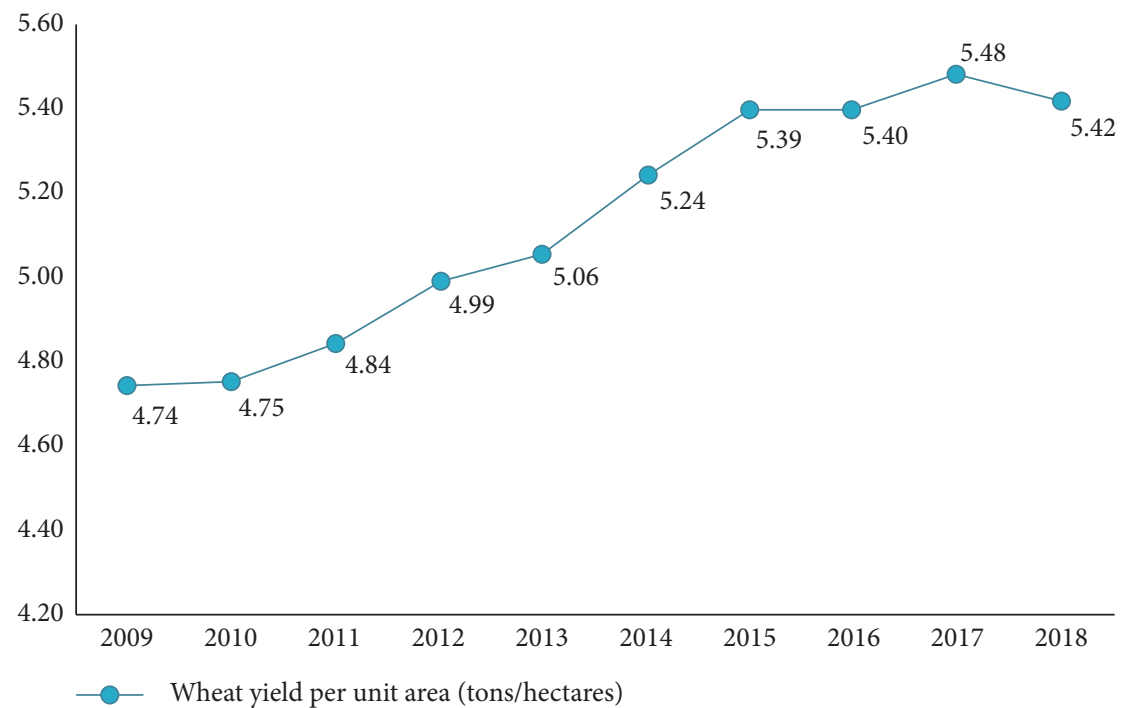

Figure 2: Wheat production per unit area in China from 2009 to 2018 (source: National Bureau of Statistics).

To prevent bacterial contamination, all works are performed on the ultraclean workbench.

\subsubsection{Identification of Bacteria and Determination of Pop-} ulation Toxicity. After the first leaf of the seedlings of 26 wheat varieties was fully expanded, the isolated leaves of the seedlings were inoculated according to the Wolfe method [27-29]. $60 \mathrm{mg} / \mathrm{kg}$ benzimidazole aqueous solution was dripped on straw to avoid infection by miscellaneous bacteria and kept fresh for about 10 days. The reaction level of each variety (line) of powdery mildew strain was recorded, and the experiment was repeated twice.

According to the infection type, the reaction levels of each variety (line) to powdery mildew strains were divided into six grades, which were 0,$0 ; 1,2,3$, and 4 , among which
0 2 were nontoxic (resistant, $\mathrm{R}$ type) and 3 4 were virulent (susceptible, $\mathrm{S}$ type).

Type 0, immune plant without disease spot; type 0; necrotic reaction leaf with the withered spot; type 1 , high resistance, small disease spots (usually less than $1 \mathrm{~mm}$ in diameter), thin mycelium layer, green leaf surface, occasional large disease spots, but still transparent green, very little spore production; type 2 , medium resistance, the diameter of disease spot is less than $1 \mathrm{~mm}$, but the mycelium layer is thick and impermeable to green and can produce a certain amount of spores; type 3, middle sensation, leaf lesion diameter is generally more than $1 \mathrm{~mm}$, mycelium layer is thick, spore production is large, but the disease spot is not connected; type 4, high susceptibility, leaf disease spot diameter is generally more than $1 \mathrm{~mm}$, mycelium layer is thick, spore production is large, and disease spot is continuous. 


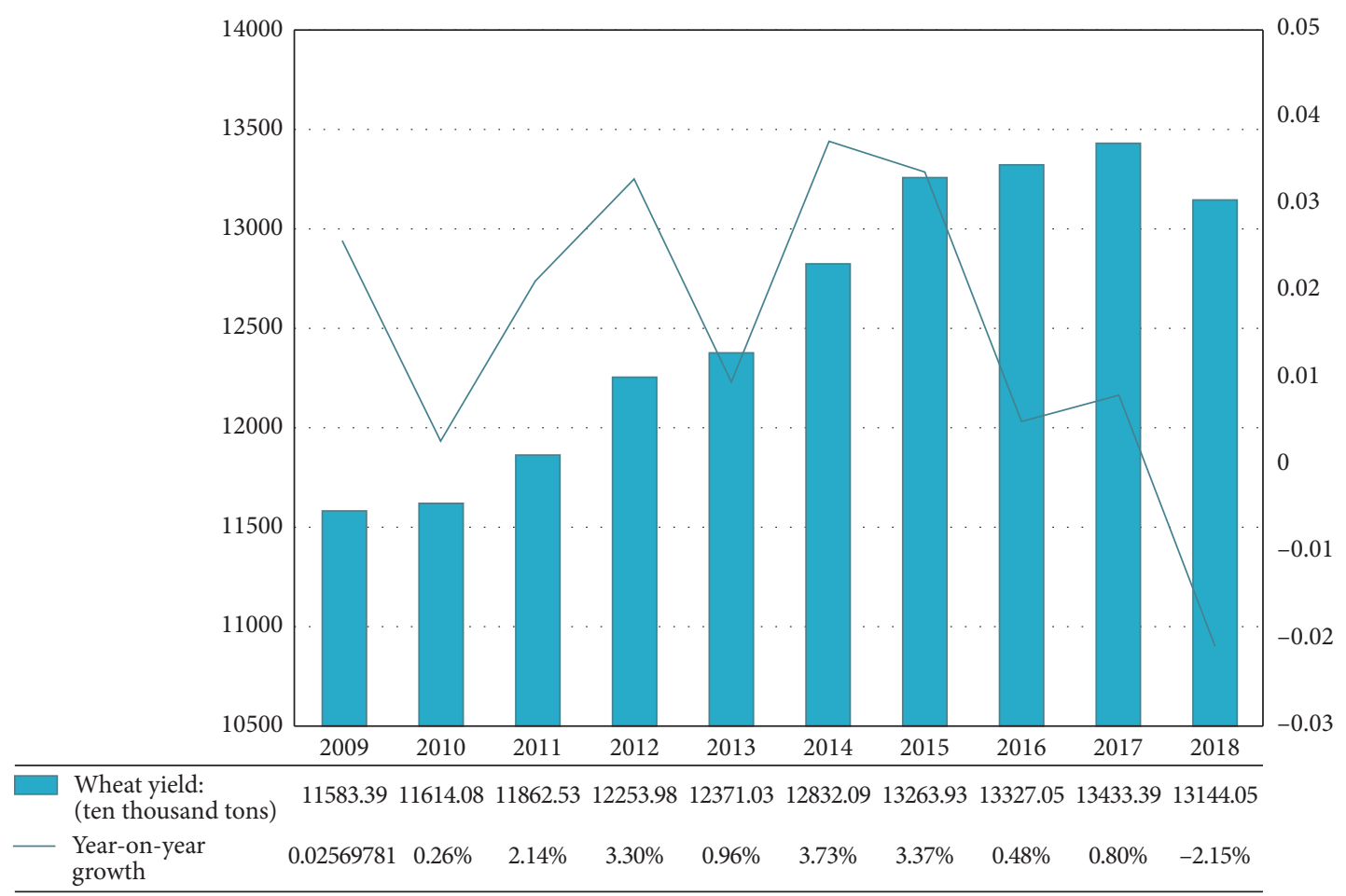

Figure 3: China's wheat production and year-on-year growth changes from 2009 to 2018 (source: National Bureau of Statistics).

2.2.3. Data Analysis. The physiological races were analyzed by scoring 1 for the presence and 0 for the absence of bands that regularly appeared at the same positions in repeated electrophoretic runs $[30,31]$. These data were tabulated into a matrix from which a phenogram was constructed by the unweighted pair group method with arithmetic means (UPGMA), using the cluster analysis program SPSS 19.0 version $[32,33]$.

Genetic distance is calculated by the Euclidean distance formula:

Two-dimensional plane Euclidean distance:

$$
d 12=\left(x_{1}-x_{2}\right)^{2}+\left(y_{1}-y_{2}\right)^{2} .
$$

Euclidean distance in three-dimensional space:

$$
d_{12}=\left(x_{1}-x_{2}\right)^{2}+\left(y_{1}-y_{2}\right)^{2}+\left(z_{1}-z_{2}\right)^{2} .
$$

Euclidean distance in multidimensional space:

$$
d_{12}=\sum_{k=1}^{n}\left(x_{1 k}-x_{2 k}\right)^{2}
$$

Standardized Euclidean distance:

$$
d_{12}=\sum_{k=1}^{n}\left(\frac{x_{1 k}-x_{2 k}}{s_{k}}\right)^{2},
$$

where $S$ is the standard deviation.

In the UPGMA, the average distance between the new classification and other classifications is weighted according to the trees of each taxon. Besides $x$ and $y$ form a new classification as $(x y)$, the distance from the new classification to other classes $U$ is calculated according to formula (5).

$$
d_{(\mathrm{xy}), u}=\left(\frac{n_{x}}{n_{x}+n_{y}}\right) d_{x, u}+\left(\frac{n_{y}}{n_{x}+n_{y}}\right) d_{y, u}
$$

where $n_{x}, n_{y}$, and $n_{x}+n_{y}$ are the elements of type $x, y$, and (xy), respectively.

\section{Results and Analysis}

3.1. Identification Results of Physiological Races. A total of 36 standard samples of powdery mildew were purified by in vitro inoculation and living glass cover inoculation, and 20 physiological races were identified, as given in Table 1, indicating that the structure of physiological races of wheat powdery mildew in Hebei province is complex. Among them, the highest occurrence frequency (that is the dominant race) is 015 , the distribution frequency is $16.7 \%$, followed by 077 , the occurrence frequency is $11.1 \%$, which is the second dominant race. Besides, the ratio of highly toxic races is large, for example, the virulence frequency of races 4 , 6 , and 9 is more than $22 \%$, which is higher than $16.7 \%$ of dominant race 015 , and highly toxic races such as $415-717$ account for $22.4 \%$. It is also higher than the distribution frequency of dominant race 015 , indicating that the pathogenicity of wheat powdery mildew race in Hebei province is strong.

The octal method is adopted, and the larger the race number is, the wider the Poisson spectrum is and the stronger the virulence is. According to the classification of low virulence (0-7), medium virulence (10-77), and high virulence (100-77), the occurrence frequencies of the three types of small populations in this experiment were $11.2 \%$, $50.2 \%$, and $39.2 \%$, respectively, compared with the 
TABle 1: Physiologic race identification of Blumeria graminis f.sp. tritici in central Hebei province, 2019.

\begin{tabular}{|c|c|c|c|c|c|c|c|c|c|c|c|c|c|}
\hline $\begin{array}{l}\text { Physiologic } \\
\text { race }\end{array}$ & $\begin{array}{c}9 \\
\text { Xiaobai } \\
\text { Dong }\end{array}$ & $\begin{array}{c}8 \\
\text { Baimian } \\
3\end{array}$ & $\begin{array}{c}7 \\
\text { Kenguia }\end{array}$ & $\begin{array}{c}6 \\
\text { Maris } \\
\text { Huntsman }\end{array}$ & $\begin{array}{c}5 \\
\mathrm{CI}_{12632} \\
\end{array}$ & $\begin{array}{c}4 \\
\text { Caucasus }\end{array}$ & $\begin{array}{c}3 \\
\text { Era }\end{array}$ & $\begin{array}{c}2 \\
\text { UIka/ } \\
\text { Cc8 }\end{array}$ & $\begin{array}{c}1 \\
\text { Afu }\end{array}$ & $\begin{array}{c}\text { Race } \\
\text { quantity }\end{array}$ & $\begin{array}{c}\text { Race } \\
\text { frequency }\end{array}$ & Class & $\begin{array}{c}\text { Class } \\
\text { frequency }\end{array}$ \\
\hline 001 & & & & & & & & & $S$ & 2 & 5.6 & 1 & \\
\hline 005 & & & & & & & S & & $S$ & 2 & 5.6 & 3 & \\
\hline 011 & & & & & & S & & & $S$ & 2 & 5.6 & 4 & 22.3 \\
\hline 015 & & & & & & S & S & & S & 6 & 16.7 & & \\
\hline 035 & & & & & $S$ & $S$ & $S$ & & $S$ & 2 & 5.6 & 5 & 5.6 \\
\hline 055 & & & & S & & S & S & & S & 1 & 2.8 & & \\
\hline 057 & & & & S & & S & S & $S$ & $S$ & 1 & 2.8 & 6 & 22.3 \\
\hline 067 & & & & S & S & & S & S & $S$ & 2 & 5.6 & & \\
\hline 077 & & & & S & S & S & S & S & S & 4 & 11.1 & & \\
\hline 101 & & & $S$ & & & & & & S & 2 & 5.6 & & \\
\hline 111 & & & S & & & S & & & S & 1 & 2.8 & 7 & 11.2 \\
\hline 115 & & & $S$ & & & S & S & & $S$ & 1 & 2.8 & & \\
\hline 217 & & $S$ & & & & S & S & $S$ & S & 1 & 2.8 & 8 & 5.6 \\
\hline 315 & & $S$ & S & & & S & $S$ & & $S$ & 1 & 2.8 & & \\
\hline 415 & $S$ & & & & & S & S & & $S$ & 2 & 5.6 & & \\
\hline 435 & $S$ & & & & $S$ & S & S & & $S$ & 1 & 2.8 & 9 & 22.4 \\
\hline 437 & S & & & & S & S & S & $S$ & $S$ & 2 & 5.6 & & \\
\hline 457 & $S$ & & & $S$ & & S & S & S & $S$ & 1 & 2.8 & & \\
\hline 477 & $S$ & & & S & $S$ & S & S & $S$ & $S$ & 1 & 2.8 & & \\
\hline 717 & $S$ & S & $S$ & & & S & S & $S$ & $S$ & 1 & 2.8 & & \\
\hline
\end{tabular}

TAвLE 2: Group virulence frequency of Blumeria graminis f.sp. tritici in central Hebei province, 2019.

\begin{tabular}{|c|c|c|c|c|}
\hline Strain & Resistant genes & Number virulent isolates & Virulent genes & Frequency of virulent genes \\
\hline Afu & - & 36 & - & 100.0 \\
\hline Ulka/8Cc & 2 & 13 & $\mathrm{~V}_{2}$ & 36.1 \\
\hline Era & Era & 29 & $\mathrm{~V}_{\text {Era }}$ & 80.6 \\
\hline Caucasus & 8 & 28 & $\mathrm{~V}_{8}$ & 77.8 \\
\hline $\mathrm{CI}_{12632}$ & 2,6 & 12 & $\mathrm{~V}_{2,6}$ & 33.3 \\
\hline Maris Huntsman & $2,6, ?$ & 10 & $\mathrm{~V}_{2,6, ?}$ & 27.8 \\
\hline Kenguia 1 & 4 & 6 & $\mathrm{~V}_{4}$ & 16.7 \\
\hline Baimian 3 & 4 & 3 & $\mathrm{~V}_{4}$ & 8.3 \\
\hline Xiaobai Dong & $\mathrm{XBD}$ & 8 & $\mathrm{~V}_{\mathrm{XBD}}$ & 22.2 \\
\hline Chancellor & 0 & 31 & 0 & 86.1 \\
\hline Axminster/8Cc & 1 & 26 & $\mathrm{~V}_{1}$ & 72.2 \\
\hline Asosan/8Cc & $3 a$ & 13 & $\mathrm{~V}_{3 \mathrm{a}}$ & 36.1 \\
\hline $\mathrm{Chul} / 8 \mathrm{Cc}$ & $3 b$ & 10 & $\mathrm{~V}_{3 \mathrm{~b}}$ & 27.8 \\
\hline Sonora/8Cc & $3 c$ & 30 & $\mathrm{~V}_{3 \mathrm{c}}$ & 83.3 \\
\hline Michigan Amber/8Cc & $3 f$ & 31 & $\mathrm{~V}_{3 \mathrm{f}}$ & 86.1 \\
\hline Khapli/8Cc & $4 a$ & 17 & $\mathrm{~V}_{4 \mathrm{a}}$ & 47.2 \\
\hline Armada & $4 \mathrm{~b}$ & 3 & $\mathrm{~V}_{4 \mathrm{~b}}$ & 8.3 \\
\hline Hope & 5 & 19 & $\mathrm{~V}_{5}$ & 52.8 \\
\hline Timgalen & 6 & 24 & $\mathrm{~V}_{6}$ & 66.7 \\
\hline $\mathrm{CI}_{14189}$ & 7 & 17 & $\mathrm{~V}_{7}$ & 47.2 \\
\hline \multirow[t]{3}{*}{ Amigo } & 17 & 20 & $\mathrm{~V}_{17}$ & 55.6 \\
\hline & 19 & 12 & $\mathrm{~V}_{19}$ & 33.3 \\
\hline & 20 & 1 & $\mathrm{~V}_{20}$ & 2.8 \\
\hline Yangmai5/Sub.6v & 21 & 2 & $\mathrm{~V}_{21}$ & 5.6 \\
\hline Maris Dove & 2,MID & 4 & $\mathrm{~V}_{2, \mathrm{MID}}$ & 11.1 \\
\hline Normadie & $1,2,9$ & 8 & $\mathrm{~V}_{1,2,9}$ & 22.2 \\
\hline
\end{tabular}

previously reported frequency of three types of small populations in China $(1.2 \%, 51.1 \%$, and $33.7 \%$, respectively). The occurrence frequency of highly virulent races in this experiment is slightly higher than the national average. Compared with the reported occurrence frequency of three types of small populations in Guizhou province $(25.7 \%$, $13.9 \%$, and $60.4 \%$ ), the occurrence frequency of moderately virulent small populations was significantly higher, which showed that the virulence of wheat powdery mildew in Hebei province was relatively high and the disease was 
relatively serious in production. Another characteristic is that the emergence of wheat powdery mildew has its obvious regional characteristics. The monitoring and communication of physiological races of wheat powdery mildew should be strengthened as an important parameter for the control of wheat powdery mildew.

\subsection{Virulence Gene Frequency of Pathogen Population.} The virulence gene frequencies of 36 powdery mildew strains with 26 known resistance gene varieties (lines) are given in Table 2, in which the frequency of virulence genes $V_{E r a}, V_{8}$, $\mathrm{V}_{1}, \mathrm{~V}_{3 \mathrm{c}}$, and $\mathrm{V}_{3 \mathrm{f}}$ is more than $70 \%$. The frequency of $\mathrm{V}_{17}, \mathrm{~V}_{7}$, $\mathrm{V}_{6}, \mathrm{~V}_{5}$, and $\mathrm{V}_{4 \mathrm{a}}$ is $47.2 \% \sim 66.7 \%$, and the frequency of $\mathrm{V}_{2}$, $\mathrm{V}_{2,6}, \mathrm{~V}_{2,6, ?}, \mathrm{~V}_{\mathrm{XBD}}, \mathrm{V}_{3 \mathrm{a}}, \mathrm{V}_{3 \mathrm{~b}}$, and $\mathrm{V}_{1,2,9}$ is between $20 \%$ and $36.1 \%$, respectively. Only the frequency of virulent genes in $\mathrm{V}_{2, \mathrm{MID}}, \mathrm{V}_{20}, \mathrm{~V}_{21}, \mathrm{~V}_{4 \mathrm{~b}}$, and $\mathrm{V}_{4}$ was low, which indicated that the varieties containing $\mathrm{Pm}_{2, \mathrm{MID}}, \mathrm{Pm}_{20}, \mathrm{Pm}_{21}, \mathrm{Pm}_{4 \mathrm{~b}}, \mathrm{Pm}_{4}$, and other disease resistance genes could be used to extent, especially Amigo, Yangmai 5/Sub.6v, and Armada Baimian 3 could still be used in wheat disease resistance breeding. However, the varieties carrying these resistance genes have appeared virulent strains in production. In practice, the virulence changes of these varieties should be closely tracked, and the combination of new resistance genes should be used in time. The cultivation of varieties with long-lasting resistance is the basic idea in disease resistance breeding.

\section{Conclusion}

China's grain output is still on the rise in the short term. As wheat production itself is a complex economic and natural process, it is affected by institutional, economic, and natural factors, some of which are not artificially controllable, so the actual yield may not be consistent with the predicted value. The continuous decline in reserves of existing fossil and petroleum-based fuels, undesirable environmental effects, and the associated price has made it necessary to replace the fossil fuel-based energy generation with clean, sustainable, and renewable source-based energy generation [34-37]. Biofuel production from abundant and readily accessible resources such as lignocellulosic biomass (agricultural residues, forest residues, and crop residues) is a cost-effective and sustainable solution to this challenge [38-41]. Wheat is the majorly cultivated cereal crop around the world. According to the Food and Agriculture Organization (FAO) 2014, maize, wheat, and rice are the major cultivated crops all over the world. The production of wheat is more than 700 million tonnes (MT), and European Union, China, India, United States, and Russian Federation are the major producers [42-45].

This study showed that the physiological races of wheat powdery mildew in the central part of Hebei province had complex structure and strong toxicity. The frequencies of dominant races and genotoxicity in this study are consistent with those reported in the past [46-49], indicating that although the frequency of high virulent races of wheat powdery mildew is high, the dominant races of wheat powdery mildew in Hebei province have been relatively stable since 1998. However, relatively few physiological races were identified in this experiment, which was related to the small number of total standard samples of wheat powdery mildew.

In this study, most of the standard samples were collected from the high-altitude areas in the middle and south of Hebei province, and its geographical climate and ecological environment were conducive to the occurrence and reproduction of wheat powdery mildew and create conditions for the annual cycle of the bacteria. Besides, the pathogens occurred late in high-altitude areas, which may be used as the primary infection source of powdery mildew in other winter wheat areas and early spring wheat areas [50-54]. Therefore, the distribution of intermediate hosts and the overcome situation of wheat powdery mildew in these areas should be studied in future work, which will provide a theoretical basis for controlling the primary infection of wheat powdery mildew and formulating the overall control strategy.

The results also showed that there were some differences in virulence structure and virulence frequency among wheat powdery mildew populations in different regions, and the relative virulence frequency in the Baoding region was low, which was significantly different from that in other areas. This provides a possibility and plays an important guiding role in the distribution of disease resistance genes macroscopically. Domestic wheat powdery mildew experts have recognized that wheat powdery mildew in China has regional epidemic characteristics, and the differences in virulence structure can sometimes be effectively used in disease resistance breeding, making it a kind of biological resource. For example, breeding and identification of varieties (lines) considered being resistant to wheat powdery mildew in Guizhou, plantings in other areas of Hebei province often show good resistance for some time, or even genes that have failed in Guizhou. Two other wheat production areas are still valid.

In a word, the complex distribution of wheat powdery mildew poses a great threat to the production of wheat in Hebei province. The instability of resistant materials and the variation and complexity of resistance combinations in production and application deserve the attention of breeders and plant disease workers. While creating high-quality disease-resistant resources and introducing a large number of disease-resistant resources, it is necessary to make full and rational use of the current disease-resistant materials, not only to prevent the emergence of new races in a short period. And to a certain extent, it can delay the loss of resistance of the popularized varieties.

\section{Data Availability}

The data used to support the findings of this study are available from the corresponding author upon request.

\section{Conflicts of Interest}

The authors declare that they have no conflicts of interest. 


\section{Authors' Contributions}

Qingping Zhou performed the experiment investigations, data analysis, and wrote the original manuscript. Lingli Li provided parts of resources and materials. Long Wang conceived and designed the experiments, contributed reagents/materials/analysis tools, and wrote the article. All authors reviewed the article.

\section{Acknowledgments}

The research was supported by the Science and Technology Research Project of Colleges and Universities in Hebei Province (ZD2020403), Scientific Research Project of Tangshan Normal University (2020A13), and Agricultural Science and Technology Projects of Tangshan, China (19150203E).

\section{References}

[1] J. Ma and W. Ren, "Complexity and hopf bifurcation analysis on a kind of fractional-order IS-LM Macroeconomic system," International Journal of Bifurcation and Chaos, vol. 26, no. 11, Article ID 1650181, 2016.

[2] K. N. Dodhia, B. A. Cox, R. P. Oliver, and F. J. Lopez-Ruiz, "Rapid in situ quantification of the strobilurin resistance mutation G143A in the wheat pathogen Blumeria graminis $\mathrm{f}$. sp. tritici," Scientific Reports, vol. 11, no. 1, 2021.

[3] P. Pepó, Diallel Analysis of Mildew (Blumeriagraminis F. sp. tritici.) and Leaf Rust (PucciniaRecondita F. Sp. tritict.) in Winter Wheat Genotypes, Cereal Research Communications: Founded by the Cereal Research Non-Profit Ltd., Cham, Switzerland, 2006.

[4] S. Rosanna, P. Luciana, N. Domenica et al., "Mapping powdery mildew (Blumeriagraminis $\mathrm{f}$. sp. tritici) resistance in wild and cultivated tetraploid wheats," International Journal of Molecular Sciences, vol. 21, 2020.

[5] J. Ma, Y. Li, and Z. Wang, "Analysis of pricing and services effort in dual-channel supply chains with showrooming effect," International Journal of Bifurcation and Chaos, vol. 30, no. 16, 21 pages, Article ID 2050241, 2020.

[6] J. Ma and L. Sun, "Complexity analysis about nonlinear mixed oligopolies game based on production cooperation," IEEE Transactions on Control Systems Technology, vol. 26, no. 4, pp. 1532-1539, 2018.

[7] L. Jia, Li Sun, Y. Chen et al., "The regulatory network of CMPG1-V in wheat-Blumeriagraminis f. sp. tritici interaction revealed by temporal profiling using RNA-seq," International Journal of Molecular Sciences, vol. 17, 2020.

[8] C. Admire, "An assessment of the critical constraints to wheat production in Zimbabwe," Business \& Social Sciences Journal, vol. 1, pp. 33-48, 2017.

[9] J. Köhl, H. Goossen-van de Geijn, L. Groenenboom-de Haas, and M. Wikström, "Stepwise screening of candidate antagonists for biological control of Blumeria graminis f. sp. tritici," Biological Control, vol. 136, no. 3, Article ID 104008, 2019.

[10] D. L. Wang, F. Hao, and L. Yi, "Energy input-output, water use efficiency and economics of winter wheat under gravel mulching in Northwest China," Agricultural Water Management, vol. 222, pp. 354-366, 2019.

[11] B. S. Bao, J. H. Ma, and M. Goh, "Short-and long-term repeated game behaviours of two parallel supply chains based on government subsidy in the vehicle market," International
Journal of Production Research, vol. 58, no. 24, pp. 7507-7530, Article ID 1711988, 2020.

[12] J. H. Ma, Y. M. Hou, Z. X. Wang, and W. H. Yang, "Pricing strategy and coordination of automobile manufacturers based on government intervention and carbon emission reduction," Energy Policy, vol. 148, Article ID 111919, 2021.

[13] P. GanL, "RAPD analysis of wheat powdery mildew (Blumeria graminis $f$. sp. tritici) and phylogenetic study of powdery mildews from different hosts," Master thesis. Hebei Agricultural University, Lanzhou, China, in Chinese, , Master thesis. Hebei Agricultural University, Lanzhou, China, in Chinese2004.

[14] J. Ma and Y. Liu, "Exact solutions for a generalized nonlinear fractional Fokker-Planck equation," Nonlinear Analysis: Real World Applications, vol. 11, no. 1, pp. 515-521, 2010.

[15] J. Song, Z. Niu, Q. Li, and D. Feng, "Isolation and identification of differentially expressed genes from wheat in response to Blumeria graminis f. sp. tritici (Bgt)," Plant Molecular Biology Reporter, vol. 33, no. 5, p. 1371, 2015.

[16] L. Věchet, "Reaction of winter wheat cultivars and breeding lines to Blumeriagraminis f. sp. tritici," Plant Protection Science, vol. 6, 2006.

[17] Z. Xu, "Genetic diversity of Blumeriagraminis f. sp. tritici populations in part of wheat growing areas in China," Master thesis.Fujian Agriculture and Forestry University, Fuzhou, China, in Chinese, , Master thesis.Fujian Agriculture and Forestry University, Fuzhou, China, in Chinese2010.

[18] L. Xie, J. Ma, and M. Goh, "Supply chain coordination in the presence of uncertain yield and demand," International Journal of Production Research, vol. 2020, no. 5, p. 1, 2020.

[19] X. Ren, B. Shang, Z. Feng, and V. Calatayud, "Yield and economic losses of winter wheat and rice due to ozone in the Yangtze River Delta during 2014-2019," Science of the Total Environment, vol. 745, Article ID 140847, 2020.

[20] P. GanL and R. WangS, "RAPD analysis of wheat powdery mildew(Blumeriagraminisf.sp.tritici) in the mid-west of Hebei province," Journal of Henan Agricultural Sciences, vol. 02, pp. 64-67, 2009, in Chinese.

[21] O. V. Babayants, L. T. Babayants, V. A. Traskovetskaya, and A. V. Galaev, Race Composition of Blumeriagraminis (DC) Speer f. sp. tritici in the South of Ukraine and Effectiveness of Pm -genes in 2004-2013, Cereal Research Communications: Founded by the Cereal Research Non-Profit Ltd., Cham, Switzerland, 2015.

[22] D. Han, G. S. Li, and Y. Zhong, "Study on the comparison of grain competitiveness and the influencing factors of grain trade between China and the countries along Belt and road initiative," Journal of Jiangxi University of Finance and Economics, vol. 22, no. 04, pp. 76-92, 2020, in Chinese.

[23] S. H. Wei, Y. Z. Zhang, and L. B. Zhang, "Determination and RAPD analysis of physiological strain of Erysiphegraminis in the northeastern spring wheat area of China," Journal of Jilin Agricultural University, vol. 02, pp. 35-40, 2001, in Chinese.

[24] S. Gong, L. Yang, L. Xiang, and D. Yu, "An approach for longterm preservation of Blumeria graminis f. sp. tritici," Tropical Plant Pathology, vol. 40, no. 2, p. 127, 2015.

[25] S. Hossein, F. Hassan, and K. Alireza, "Is saffron more energy and economically efficient than wheat in crop rotation systems in northeast Iran?" Sustainable Production and Consumption, vol. 5, pp. 29-35, 2016.

[26] W. Lou and J. Ma, "Complexity of sales effort and carbon emission reduction effort in a two-parallel household appliance supply chain model," Applied Mathematical Modelling, vol. 64, pp. 398-425, 2018. 
[27] M. S. Wolfe, "Use of benzimidazole in the study of wheat powdery mildew," Transactions of the British Mycological Society, vol. 46, p. 620, 1963.

[28] J. Riechen, "Establishment of broad-spectrum resistance against Blumeria graminis f.sp. tritici in Triticum aestivum by RNAi-mediated knock-down of MLO," Journal für Verbraucherschutz und Lebensmittelsicherheit, vol. 2, no. S1, p. 120, 2007.

[29] F.-s Zeng, L.-s Yang, S.-j Gong et al., "Virulence and diversity of Blumeriagraminis $f$. sp. tritici populations in China," Journal of Integrative Agriculture, vol. 13, no. 11, pp. 2424-2437, 2014.

[30] M. Stamatis, I. Constantine, T. Irini, and P. Eugenia, "Perennial energy crops vs. durum wheat in low input lands Economic analysis of a Greek case study," Renewable and Sustainable Energy Reviews, vol. 80, pp. 789-800, 2017.

[31] J. Shen, Q. Zhang, and R. H. Zhang, "Co-pretreatment of wheat straw by potassium hydroxide and calcium hydroxide: methane production, economics, and energy potential analysis," Journal of Environmental Management, vol. 236, pp. 720-726, 2019.

[32] Y.Y. He, "Study on the price guidance function of the Chinese wheat futures market to the spot market," Master thesis. Shenyang Normal University, Shenyang, China, in Chinese, , Master thesis. Shenyang Normal University, Shenyang, China, in Chinese2016.

[33] E. M. Eid, T. M. Galal, and A. F. El-Bebany, "Prediction models for monitoring heavy-metal accumulation by wheat (Triticum aestivum L.) plants grown in sewage sludge amended soil," International Journal of Phytoremediation, vol. 22, no. 10, pp. 1000-1008, 2020.

[34] W. Hu, L. Yan, and Z. Ma, "Cloning and expression analysis of a putative $\mathrm{ABC}$ transporter GeneBgABC1from the Biotrophic pathogenic FungusBlumeria graminisf. sp.tritici," Journal of Phytopathology, vol. 156, no. 2, p. 120, 2008.

[35] Q. Gao and J. Ma, "Chaos and Hopf bifurcation of a finance system," Nonlinear Dynamics, vol. 58, no. 1-2, pp. 209-216, 2009.

[36] P. Prateek, N. K. Khandelwal, G. Chanchal et al., "Energy requirement and economic viability of raised bed planters for WheatProduction in vertisol," International Journal of Agriculture Sciences, vol. 10, no. 8, pp. 5885-5889, 2018.

[37] A. Maryam, O. O. Adetoyese, and A. Kumar, "Techno-economic assessment of wet and dry torrefaction of biomass feedstock," Energy, vol. 207, Article ID 118287, 2020.

[38] L. Vechet, L. Burketova, and M. Sindelarova, "A comparative study of the efficiency of several sources of induced resistance to powdery mildew (Blumeria graminis f. sp. tritici) in wheat under field conditions," Crop Protection, vol. 28, no. 2, p. 151, 2009.

[39] J. Ma and L. Xie, "The comparison and complex analysis on dual-channel supply chain under different channel power structures and uncertain demand," Nonlinear Dynamics, vol. 83, no. 3, pp. 1379-1393, 2016.

[40] S. Li, J. C. Wu, X. Q. Wang, and L. Ma, "Economic and environmental sustainability of maize-wheat rotation production when substituting mineral fertilizers with manure in the North China Plain," Journal of Cleaner Production, vol. 271, Article ID 122683, 2020.

[41] S. Amir, B. Haithem, C. M. Hatem, and A. Mohamed, "Effect of tillage, previous crop, and $N$ fertilization on agronomic and economic performances of durum wheat (Triticum durum desf.) under rainfed semi-arid environment," Agronomy, vol. 10, no. 8, Article ID 10081161, 2020.
[42] J.-H. Wu, Y.-G. Hu, H. Zhange, and J. I. Wan-Quan, "Expression of special genes resistant to powdery mildew (Blumeriagraminis f. sp. tritici) in wheat germplasm N9436," Acta Agronomica Sinica, vol. 7, 2008.

[43] S. Alessandro, B. Simone, and A. Vincenzo, "Economic distance to gather agricultural residues from the field to the integrated biomass logistic centre: a Spanish case-study," Energies, vol. 12, no. 16, Article ID 12163086, 2019.

[44] T. Johan and J. Ann-Sofi, "Techno-economic impact of air sparging before purification of alkaline extracted wheat bran hemicelluloses by membrane filtration," Separation and $\mathrm{Pu}$ rification Technology, vol. 253, Article ID 117498, 2020.

[45] J. H. Ma, Y. M. Hou, W. H. Yang, and Y. Tian, "A time-based pricing game in a competitive vehicle market regarding the intervention of carbon emission reduction," Energy Policy, vol. 142, Article ID 111440, 2020b.

[46] L. Wang, S. R. Wang, and L. P. Gan, "Group virulence study of Blumeria graminis f. sp. tritici in the mid-west of Hebei province, China," Acta Agriculturae Boreali Occidentalis Sinica, vol. 01, pp. 110-114, 2005.

[47] J.-L. Genet and G. Jaworska, "Baseline sensitivity to proquinazid in Blumeria graminis f. sp. tritici and Erysiphe necator and cross-resistance with other fungicides," Pest Management Science, vol. 65, no. 8, p. 878, 2009.

[48] B. Batidzirai, M. Valk, and B. Wicke, "and future technical, economic and environmental feasibility of maize and wheat residues supply for biomass energy application: illustrated for South Africa," Biomass and Bioenergy, vol. 92, pp. 106-129, 2016.

[49] L Cong, "Research on basis risk of hedging in the wheat futures market of China," Master thesis. Tianjin University of Commerce, Tianjin, China, in Chinese, , Master thesis. Tianjin University of Commerce, Tianjin, China, in Chinese2019.

[50] J. Vogel, T. K. Raab, and C. Schiff, "PMR6, a pectate lyase-like gene required for powdery mildew susceptibility in arabidopsis," The Plant Cell, vol. 14, no. 9, pp. 2095-2106, 2002.

[51] C. Cowger, R Parks, and D Marshall, "The appearance of powdery mildew of wheat caused by Blumeriagraminis $\mathrm{f}$. $\mathrm{sp}$. tritici on Pm17-bearing cultivars in North Carolina," Plant Disease, vol. 11, 2009.

[52] A. Adam, "An Islamic monetary theory of value and equation of exchange: evidence from Egypt (696-1517)," Humanomics, vol. 32, no. 2, pp. 121-150, 2016.

[53] J. Ma and H. Ren, "Influence of government regulation on the stability of dual-channel recycling model based on customer expectation," Nonlinear Dynamics, vol. 94, no. 3, pp. 1775-1790, 2018.

[54] T. Xu and J. Ma, "Feed-in tariff or tax-rebate regulation? Dynamic decision model for the solar photovoltaic supply chain," Applied Mathematical Modelling, vol. 89, pp. 1106-1123, 2021. 